\title{
PERANCANGAN JARINGAN LOCAL AREA NETWORK (LAN) DAN DNS SERVER MENGGUNAKAN ROUTING PROTOKOL OPEN SHORTEST PATH FIRST (OSPF) PADA BUMIPUTERA BANDAR JAYA
}

\author{
Sidik Rahmatullah, S.Kom ${ }^{1}$, Anggeraini ${ }^{2}$ \\ ${ }^{1}$ Dosen Sistem Komputer, STMIK Dian Cipta Cendikia Lampung \\ ${ }^{1}$ Sidik@dcc.ac.id \\ ${ }^{2}$ Mahasiswa Manajemen Informatika, AMIK Dian Cipta Cendikia Lampung
}

\begin{abstract}
ABSTRAK
Jaringan komputer merupakan suatu sistem yang terdiri dari komputer dan perangkat lainnya yang dirancang untuk dapat bekerja bersama-sama dalam berbagai manfaat dan tujuan antara lain untuk berkomunikasi, akses informasi, menerima maupun memberikan layanan. Bagian yang menerima layanan disebut Client dan bagian yang memberikan layanan disebut Server. Sistem ini dikenal sebagai sistem client-server yang sudah digunakan pada hampir seluruh aplikasi jaringan komputer. Saat ini banyak instansi tertentu yang menggunakan jaringan LAN (Local Area Network). LAN merupakan suatu kumpulan komputer, dimana terdapat beberapa unit komputer (client) dan satu unit komputer untuk bank data (server).
\end{abstract}

Tahapan-tahapan yang dilakukan pada tugas akhir ini memiliki beberapa tahapan, yaitu mencari dan mengumpulkan data apa saja yang dibutuhkan untuk merancang sebuah jaringan komputer LAN dengan DNS Server menggunakan routing protokol OSPF setelah data yang diperlukan terkumpul adalah melakukan proses lebih lanjut data tersebut diolah sebagai masukan untuk merancang sebuah jaringan sederhana, setelah itu tahapan selanjutnya adalah menentukan kebutuhan sistem dan melakukan simulasi terlebih dahulu.

Jaringan komputer yang dirancang pada Kantor Bumiputera Bandar Jaya sangat membantu mempermudah proses kinerja staff dan karyawan untuk dapat saling bertukar data dan informasi, Efektifitas jaringan komputer akan meningkat jika menggunakan metode dan konfigurasi yang tepat.

Kata Kunci : Jaringan komputer Lokal (LAN), DNS Server, Routing Protokol Open Shortest Path First (OSPF).

ABSTRACK 
A computer network is a system that is composed of other computers and devices that are designed to be able to work together in a wide range of benefits and purpose among other things to communicate, access information, receive and deliver services. The receiving service is called the Client and the service are called servers. This system is known as client-server system which has been used in almost all applications of computer networks. Currently many specific instances using the LAN (Local Area Network). A LAN is a group of computers, where there are several computer units (client) and a computer unit for bank data (server).

Stages-stages made on the final task has several stages, namely seeking and collecting any data needed for designing a LAN computer network with DNS Server using routing protocols OSPF after the necessary data collected is conducting further process the data being processed as input to design a simple chain, after that the next step is to determine the needs of the system and perform simulated in advance.

A computer network that devised in office bandar jaya bumiputera very helpful to simplify the process and the performance of staff employees to able to exchange data and information and the effectiveness of a computer network will increase if using methods and just the right configuration.

Key Word: Computer Network Of Local (LAN), DNS Server, Routing Protocol Open Shortest Path First (OSPF). 